\title{
The Intergenerational Transfer Effects on Sport Activity
}

\author{
By Seppo Suominen*
}

The intergenerational transfer effects from parents to their children are strong. We are testing the intergenerational transfer hypothesis using a Finnish data set collected in 2007. The survey allows not only studying intergenerational transfer effect in sport but also in movies at a cinema and classical music concerts participation. Consumers' preferences are modelled using a CES utility function. If sport (movies, classical music) are normal goods, higher incomes result in higher demand but lost income due to time spent in these leisure activities should decrease the demand. It turns out that lost income (Linder's disease) is important. Older persons who are already pensioners do not suffer from Linder's disease are more active sport, movies and classical music consumers than younger (e.g. 55 - 64 years old). The intergenerational transfer hypothesis is verified. In general if parents have been active sport exercisers their children are also active sport exercisers. Father's influence is significant even when the person is older than 55. Mother's influence in that case is not significant. However, mother's influence is important and significant in the cases of movies at a cinema and classical music even when the person is older than 55.

Keywords: Cultural Participation, Finland, Intergenerational, Sport Activity, Transfer effects

\section{Introduction}

It is well known that children, whose parents (mother or father) are exercising sport actively, are also active sport exercisers (Hakamäki et al. 2014) but there is less knowledge how this socialisation is valid with ageing. The theory of socialisation can be used to explain changes in the behaviour of a person. The term is used by sociologists and educationalists to refer to a lifelong process of inheriting norms and habits (Handel 2006). In a society some habits or manners become accepted as these are learned from parents, friends or school. Children are open to primary socialisation as learn the attitudes and values from their family and friends. The secondary socialisation taking place outside home after the primary socialisation. Schools require different behaviour from the home and pupils must act according to these rules. When a pupil or student enters a new environment the secondary socialisation takes place (Saaristo and Jokinen 2009). The phenomenon of children exercising sport actively can be at least partially explained by the theory of socialisation in the case that parents are also active exercisers. The intergenerational transfers from adult parents to their children can be very strong as Downward et al. (2014) discover. However, the stability of such

${ }^{*}$ Senior Lecturer, Haaga-Helia University of Applied Sciences, Finland. 
behaviour is not known when other factors that have an impact on health behaviour have been taken into account. Therefore the purpose of this study is to find out is the socialisation equal among young people, adults and pensioners. Sport participation among Finnish citizens is relatively high in international comparison (Martinez-Gonzalez et al. 2001). Due to this high participation rate, it is important to find out how this socialisation is valid after other factors have been controlled. Can we expect that in the future Finnish citizens are exercising sport actively as they do now?

This study uses a data collected by Statistics Finland in autumn 2007 as a part of the larger survey focusing on cultural attitudes of the citizens in Finland excluding the Aland islands. A random sample was chosen and a letter inquiry was sent to 3,000 individuals. The response rate was $46.3 \%$, meaning that we have 1,388 respondents in the survey ${ }^{1}$. The data allows studying how the intergenerational transfer explains sport participation. Are there any differences between transfer from father and from mother? Some of the questions allow us to study how the intergenerational transfer explains other leisure-time activities, like going to see a film at a cinema or visiting a classical music concert. The particular aim of this paper is to provide an analysis of the effects of intergenerational transfer effects on their children's sports and cultural events participation. If the parents are or have been active sport exercisers, are their children also active even in the case that the children are no longer young. Is this intergenerational effect valid after decades have passed?

\section{Relevant Literature}

The socio-economic factors affect the health behaviour of individuals. Usually the socio-economic factors are measured by various human capital and income related variables, like the education of the person, age and annual incomes and property (Hakamäki et al. 2014). Some sport activities are rather expensive and less wealthy individuals cannot exercise all sports, however there are cheap alternatives like jogging or cycling. It is argued that ageing affects health behaviour by reducing the physical ability to participate in sport activities. Highly educated people seem to exercise more sport (Downward and Rasciute 2009, Lera-López and Rapún-Gárate 2007, Scheerder et al. 2005). The demand for physical activity tends to be U-shaped with a minimum at the age of 33 (García et al. 2011). Time pressures are associated with working hours of highly educated persons. Therefore the results concerning the impact of education on sport behaviour is mixed. Highly educated persons typically have higher incomes and the relative lost income due to exercising sport may reduce participation. The influence of personal incomes on the demand for time-consuming sports and other leisure activities has two channels, the direct income effect and the indirect substitution effect. If sport participation is a normal good, higher incomes results in higher demand for sports, however

\footnotetext{
${ }^{1}$ The data can be obtained from The Finnish Social Science Data Archive (FSD) http://www. fsd.uta.fi/aineistot/luettelo/FSD2953/.
} 
since sport participation is time-consuming, the time needed is more expensive in terms of lost income. The latter is the substitution effect or Linder's effect (Burenstam Linder 1970). The adverse effect of rising wages on demand (Linder's disease) has been given less attention in the literature. Løyland and Ringstad (2009) using a Norwegian data suggest that Linder's disease is important and cannot be ignored. The income - leisure approach proposes that time-consuming sport participation varies positively with incomes and negatively with earnings per hour. Nevertheless, higher incomes seem to increase the probability to engage in sport (e.g. Lechner 2009). Higher incomes, however, tend to decrease the time allocated to sports and increase the intensity or the frequency of the sport (Downward and Rasciute 2011).

The sociological and psychological sport participation theories emphasise the role of gender, previous participation and group behaviour (Downward 2007). Some social activities are related to gender. Men prefer competition in sports while women prefer individual well-being. Therefore sporting activities are partially segmented based on gender. Previous participation is important if sport participation has thee origins in childhood (Seefeldt et al. 2002). If reasonable level of physical activity becomes a habit in childhood, the regular physical activity will persist throughout adolescence and adulthood. The sporty behaviour is stable and predictable. However, longitudinal studies do not always verify that result (Seefeldt et al. 2002).

However, it is known that besides individual and family preferences and constraints that have an impact on sport participation the sport policy of the society has an influence on the health behaviour of citizens. Since the 1960's in Finland there has been a policy favouring sport for the masses (Green and Collins 2008). In the 1990's this policy was reinforced in the national policy development for sports and health. The state committee on exercise and sport emphasised the idea "sport for all" (Vuori et al. 1998). The purpose of the programme launched in the early 1990's was to promote creation of new sport and physical activity services to meet local needs, expectations and conditions. Among others one of the means was to provide financial support. There were many projects targeted at promoting sport and physical activity for children and young people but also for adults. The follow up results of these programmes reveal that the participation in leisure-time physical activity increased among adults in Finland. The high sport participation rates in Finland can be at least partially explained by the national sport and healthy policy. If it turns out that we observe intergenerational transfers effects, we can argue that the healthy policy has not only positive effects now but also in the future.

Sport participation has been studied a lot since the healthy behaviour of individuals is important not only to the participants but also to the society. Some recent summary reviews can be found in Downward et al. (2014), Cabane and Lechner (2014) or Downward and Rasciute (2015). 


\section{A Model}

Following García, Lera-López and Suárez (2011) consumers' preferences are written in terms of time spent on different leisure activities $\left(l_{1}\right.$ and $\left.l_{s}\right)$ and net income (m). The net income can be used to consumption that is not related to leisure. Leisure is used in sport $\left(l_{s}\right)$ and other than physical activities $\left(l_{1}\right)$. The structure of consumer preferences is assumed to be a CES utility function due to its convenient marginal rate of substitution (MRS) features. The consumer's optimization problem is

$$
\text { (1) } \max _{m, l_{1}, l_{s}} U\left(m, l_{1}, l_{s}\right)=\left[m^{-\rho}+\beta l_{1}^{-\rho}+\gamma l_{s}^{-\rho}\right]^{-\frac{1}{\rho}} \text { s.t. } m=w\left(T-l_{1}-l_{s}\right)+y
$$

where $\mathrm{U}$ denotes utility, $\rho$ is a parameter closely related to constant elasticity of substitution and it must be greater than $-1, \beta$ and $\gamma$ are positive parameters, $\mathrm{w}$ is hourly earnings, $\mathrm{T}$ is time available (168 hours a week) and finally y is nonlabour income. By solving the optimization problem including the budget constraint, consumer's demands for sports $\left(l_{\mathrm{s}}\right)$ and other leisure activities $\left(l_{1}\right)$ can be obtained. Interior solutions of the optimization problem denote that the MRS between net income (m) and either sports or other leisure activities must be equal to the hourly earnings:

(2) $\operatorname{MRS}_{m, l_{s}}=\frac{\partial U / \partial l_{s}}{\partial U / \partial m}=\gamma\left(\frac{m}{l_{s}}\right)^{1+\rho}=w$

(3) $M R S_{m, l_{1}}=\frac{\partial U / \partial l_{1}}{\partial U / \partial m}=\beta\left(\frac{m}{l_{1}}\right)^{1+\rho}=w$

The equations (2) and (3) indicate that the MRS between any two components in the CES utility function does not depend on the third. By processing the above we obtain the following, handy estimable expressions.

(4) $\log \left(\frac{m}{l_{g}}\right)=\frac{1}{1+\rho} \log w-\frac{1}{1+\rho} \log \gamma$

(5) $\log \left(\frac{m}{l_{1}}\right)=\frac{1}{1+\rho} \log w-\frac{1}{1+\rho} \log \beta$

The unobservable and observable factors that have an impact on leisure activities are captured through the parameters $\beta$ and $\gamma$ as follows:

(6) $\beta=e^{\left(z_{s} \theta_{s}+\varphi_{s}\right)}$

(7) $\gamma=e^{\left(z_{1} \theta_{1}+\varphi_{1}\right)}$ 
where $Z_{s}$ and $Z_{1}$ represent different socio-economic variables that have an impact on utility and leisure time activities and $\varphi_{s}$ and $\varphi_{1}$ are random variables accounting for unobservable factors. Assuming that $\varphi_{s}$ and $\varphi_{1}$ are distributed as a bivariate normal distribution with zero means and constant variances, the linear system can be estimated using the seemingly unrelated systems (SUR) method. The following equations will be estimated:

(8) $\log \left(\frac{m}{l_{s}}\right)=\frac{1}{1+\rho} \log w-\frac{1}{1+\rho}\left(Z_{s} \theta_{s}+\varphi_{s}\right)$

(9) $\log \left(\frac{m}{l_{1}}\right)=\frac{1}{1+\rho} \log w-\frac{1}{1+\rho}\left(Z_{1} \theta_{1}+\varphi_{1}\right)$

It is important to notice that sport participation $\left(l_{\mathrm{S}}\right)$ as well as other than physical activities $\left(l_{1}\right)$ are the denominators in the equations indicating that a positive sign in the estimation results means that the variable's impact is negative on sport participation or other than physical activities.

\section{Data and Prescriptive Statistics}

The data (Culture and Leisure in Finland 2007) was collected in autumn 2007 using a letter inquiry sent to 3,000 adult (aged $18-74$ ) individuals in Finland excluding the Aland islands. The response rate was $46.3 \%$. The data is a wide survey on the culture and leisure and it provides information about personal and household incomes, education, age, gender, marital status, family relations, and about cultural and sport participation. The main questions about sport participation are the following: Do you exercise any (physical) sports? How often do you exercise sport at least $30 \mathrm{~min}$ so that you at least get out of breath or sweat? Which form of physical activity do you exercise nowadays? Table 1 demonstrates that woman seem to be active exercisers, although the $\chi^{2}$-statistics $=9.7^{(*)}$ is significant only at $10 \%$ level.

Table 1. How often do you Exercise Sport at Least 30 Min so that you at Least get out of Breath or Sweat?

\begin{tabular}{|l|c|c|c|c|c|c|}
\hline & $\begin{array}{c}\text { Every } \\
\text { day }\end{array}$ & $\begin{array}{c}\text { Several } \\
\text { times a week }\end{array}$ & $\begin{array}{c}\text { Once a } \\
\text { week }\end{array}$ & $\begin{array}{c}\text { 2-3 times } \\
\text { a month }\end{array}$ & $\begin{array}{c}\text { Once a } \\
\text { month }\end{array}$ & $\begin{array}{c}\text { Less } \\
\text { frequently }\end{array}$ \\
\hline Female (N=815) & 135 & 370 & 136 & 38 & 8 & 128 \\
\hline Male (N=573) & 85 & 210 & 91 & 31 & 12 & 144 \\
\hline
\end{tabular}

Source: Author's estimations

The demand for sports is higher for individuals who exercise sport every day than for those who exercise less often. A commensurate measure for the demand for sports $\left(l_{\mathrm{s}}\right)$ is calculated in the following way: "Every day" is recoded 4 hours per week, several times a week, once a week, $2-3$ times a month or once a month 2 hours, 1 hour, 0.5 hours, 0.1 hours per week, respectively and finally less frequently is recoded 0.01 hours per week. In the current study the dependent variable's $\log \left(\frac{m}{l_{S}}\right)$ or $\log \left(\frac{m}{l_{1}}\right)$ nominator is the 
(logarithm of) net household incomes and the denominator if the (logarithm of) the demand for sports $\left(l_{\mathrm{s}}\right)$ or the demand for other leisure activities (cinema, classical music) as defined above ${ }^{1}$.

The most popular forms of physical activity in 2007 among Finnish adults were the following: walking, cycling, Nordic walking, swimming and skiing. Based on $\chi^{2}$-statistics women were more active in walking, Nordic walking and swimming while men were more active exercisers in skiing, jogging, downhill skiing and all team games, including floorball, football and ice hockey. Table 2 presents summary statistics on the forms of physical activity.

Table 2. Forms of Physical Activity, Percentages - The Gender Impact on Engagement in Sports Activities Tested with $X^{2}$-Statistics

\begin{tabular}{|c|c|c|c|c|c|c|c|c|c|c|}
\hline & 告 & 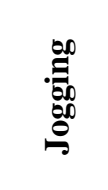 & 屬 & : & 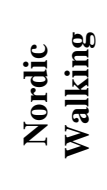 & $\underset{b}{\Xi}$ & 预 & $\frac{\frac{0}{2}}{\frac{0}{0}}$ & 氖 & 䢘 \\
\hline Female & $87.3 \%$ & $16.7 \%$ & $47.5 \%$ & $28.2 \%$ & $40.3 \%$ & $20.3 \%$ & $0.1 \%$ & $10.6 \%$ & $13.7 \%$ & $15.6 \%$ \\
\hline Male & $70.0 \%$ & $25.2 \%$ & $44.1 \%$ & $35.6 \%$ & $21.4 \%$ & $25.0 \%$ & $2.5 \%$ & $0.2 \%$ & $0.9 \%$ & $8.1 \%$ \\
\hline$\chi^{2}$ & $51.4^{* * *}$ & $12.2^{* * * *}$ & n.s. & $6.9^{* * *}$ & $44.1^{* * * *}$ & $3.4^{(*)}$ & $14.2^{* * *}$ & $47.5^{* * * *}$ & $56.0^{* * * *}$ & $13.7^{\text {**** }}$ \\
\hline & 景 & 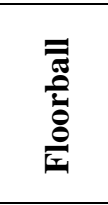 & 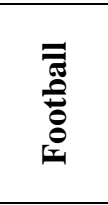 & 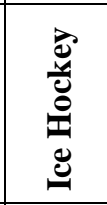 & 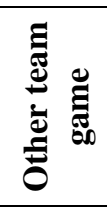 & 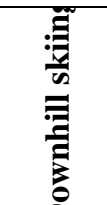 & 号 & ठै & 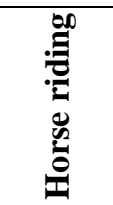 & $\frac{\bar{d}}{\tilde{D}}$ \\
\hline Female & $35.6 \%$ & $2.6 \%$ & $0.7 \%$ & $0.1 \%$ & $1.8 \%$ & $8.4 \%$ & $2.0 \%$ & $3.4 \%$ & $3.7 \%$ & $11.0 \%$ \\
\hline Male & $26.1 \%$ & $9.9 \%$ & $7.9 \%$ & $5.2 \%$ & $5.6 \%$ & $12.2 \%$ & $5.6 \%$ & $8.3 \%$ & $0.9 \%$ & $19.8 \%$ \\
\hline$\chi^{2}$ & $11.3^{* * * *}$ & $28.5^{* * * *}$ & $41.3^{* * * *}$ & $33.5^{\text {*ak }}$ & $12.0^{* * * *}$ & $4.2^{*}$ & $10.8^{* * * *}$ & $12.9^{* * * *}$ & $8.4^{* *}$ & $17.0^{* \cdots * 2}$ \\
\hline
\end{tabular}

Source: Author's estimations

The following socio-economic covariates available and used in this study are gender, education, age. The reference education alternative is not having any professional or vocational education. The age is classified using ten year ranges starting from 15 to 24 and ending at "older than 65". The reference range that is not used in the estimations is 35 to 44 years old. The reason for using the ranges is the assumption that family constraints due to parenting are likely to be highest when the parents are between 25 and 44 and presumably the family constraints will reduce physical activity. We assume that the physical activity - age relationship is neither linear nor quadratic.

One of the questions in the data is a dichotomous: Do you exercise any sports or physical activity? If the respondent answered "no", the respondent was asked to skip the next questions: "How often do you exercise sport at least 30 min so that you at least get out of breath or sweat?" and "Which forms of physical activity do you exercise?" Therefore there is a lack of information about the demand for sports, since about $20 \%$ of the respondents have skipped

\footnotetext{
${ }^{1}$ The demand for cinema or classical music concert are defined and calculated as follows: "How often do you go to ...?" About once a week $=3$ hours per week - About once a month = 0.5 hours per week $-\mathrm{A}$ few times a year $=0.1$ hours per week - Less often $=0.01$ hours per week - Never $=0.001$ hours per week.
} 
the two latter questions. This is a methodological problem and may result in endogeneity of the demand variable. To manage this problem, following García et al. (2011) the estimation method first uses a probit model for the probability of exercising any sports and get the inverse Mills ratio to solve the sample selection problem in the second step. The demand system (equations 8 and 9) is estimated using seemingly unrelated regression equations (SURE) including the inverse Mills ratio to avoid the possible endogeneity problem. A similar procedure is used to estimate the working hours per week. There are pensioners and unemployed who do not have any working hours per week. A probit model for the probability of being employed is estimated and the inverse Mills ratio is obtained. This Mills ratio is included to estimate working hours per week and with the estimated coefficients the working hours are predicted for each in the sample. The results from the probability of exercising any sports and the probability of being employed are given in Tables 8 and 9 in the Appendix.

The personal and household net income variables ${ }^{1}$ in the survey have some zero responses, the missing data is estimated assuming that incomes are determined by education, gender, age, weekly working hours and marital status. The results can be found in the Appendix. Table 3 defines the variables and their descriptive statistics used in the demand system. The household net income variable is the consumption variable that yields utility. The hourly wage variable in the right side on the equations (8) and (9) is obtained by dividing net personal incomes with working hours per month (month = week x 4).

The parents, father's and mother's interest towards sport, reading, movies and classical music were asked with the following questions: "Were your parents interested in something from the listed hobbies if you think about your childhood?" If intergenerational transfer -hypothesis is valid, we would expect that father's and mother's interest towards sport has a positive impact on the physical activity of the individual and parents' interest towards movies and classical music have a positive impact on the demand for movies and classical music, respectively.

\footnotetext{
${ }^{1}$ The original data is reported using 10 different levels, the net incomes after taxes: $1=$ less than $500 € /$ month, ..., $10=$ more than $10.000 € /$ month. We are using the interval midpoint to each observation.
} 
Table 3. Variables Used in the Study and Descriptive Statistics

\begin{tabular}{|c|c|c|c|c|}
\hline Variables & Type & & Mean & $\begin{array}{l}\text { Standard } \\
\text { deviation }\end{array}$ \\
\hline $\begin{array}{l}\text { Dependent } \\
\text { variables }\end{array}$ & & & \multicolumn{2}{|c|}{$\begin{array}{l}\text { Statistics before } \\
\text { taking logarithms }\end{array}$} \\
\hline \multirow[t]{2}{*}{$\log \left(m / l_{\text {sport }}\right)$} & $\begin{array}{l}\text { Logarithm, } \\
\mathrm{m} \sim \text { scale } \\
€\end{array}$ & $\begin{array}{c}m=\text { household monthly salaries } \\
\text { if known }(n=1026) \text {, otherwise } \\
\text { estimated }(n=362)\end{array}$ & 2768.31 & 1825.81 \\
\hline & $\begin{array}{c}1_{\mathrm{s}} \sim \text { scale } \\
\text { hours/week }\end{array}$ & $\begin{array}{l}1_{\mathrm{s}}=[0.001-4] \text { depending on } \\
\text { "How often do you exercise sport } \\
\text { at least } 30 \text { min so that you at } \\
\text { least get out of breath or sweat?" }\end{array}$ & 1.66 & 1.27 \\
\hline $\log \left(m / l_{\text {movie }}\right)$ & $\begin{array}{c}1_{\text {movie }} \sim \\
\text { scale, } \\
\text { hours/week }\end{array}$ & $\begin{array}{c}1_{\text {movie }}=[0.001-3] \text { depending on } \\
\text { "How often do you go to see a } \\
\text { film at a cinema?" }\end{array}$ & 0.094 & 0.274 \\
\hline $\log \left(m / l_{\text {classical music }}\right)$ & $\begin{array}{c}\text { 1 classical music } \\
\sim \text { scale, } \\
\text { hours/week }\end{array}$ & $\begin{array}{c}1_{\text {classical music }}=[0.001-3] \\
\text { depending on "How often do you } \\
\text { go to classical music concerts?" }\end{array}$ & 0.024 & 0.132 \\
\hline \multicolumn{5}{|l|}{$\begin{array}{l}\text { Independent } \\
\text { variables }\end{array}$} \\
\hline \multirow[t]{2}{*}{$\begin{array}{l}\log w= \\
\log (\text { monthly } \\
\text { salary/working } \\
\text { hoursx } 4)\end{array}$} & $\begin{array}{l}\text { Logarithm, } \\
\text { w=hourly } \\
\text { wage } \\
\sim \text { scale, } €\end{array}$ & Personal monthly salary & 2531.40 & 1982.04 \\
\hline & & Working hours per week & 28.30 & 15.61 \\
\hline $\begin{array}{l}\text { Vocational } \\
\text { education }\end{array}$ & Binary & $\begin{array}{c}2 \text { or } 3 \text { years after secondary } \\
\text { school }\end{array}$ & 0.295 & 0.456 \\
\hline College & Binary & $\begin{array}{c}2 \text { or } 3 \text { years after secondary or } \\
\text { upper secondary school }\end{array}$ & 0.230 & 0.421 \\
\hline Bachelor & Binary & $\begin{array}{c}3 \text { or } 4 \text { years after upper secondary } \\
\text { school }\end{array}$ & 0.097 & 0.295 \\
\hline Master & Binary & $\begin{array}{c}2 \text { or } 3 \text { years after Bachelor's } \\
\text { degree }\end{array}$ & 0.166 & 0.371 \\
\hline Doctor & Binary & $\begin{array}{c}\text { At least } 4 \text { years after Master's } \\
\text { degree }\end{array}$ & 0.022 & 0.145 \\
\hline Female & Binary & & 0.587 & 0.493 \\
\hline Age $15-24$ & Binary & & 0.109 & 0.311 \\
\hline Age $25-34$ & Binary & & 0.167 & 0.373 \\
\hline Age $35-44$ & & $\begin{array}{l}\text { Reference, excluded from the } \\
\text { estimations }\end{array}$ & 0.171 & 0.377 \\
\hline Age $45-54$ & Binary & & 0.186 & 0.389 \\
\hline Age $55-64$ & Binary & & 0.228 & 0.419 \\
\hline Age $65+$ & Binary & & 0.139 & 0.346 \\
\hline $\begin{array}{l}\text { Father interested: } \\
\text { sport }\end{array}$ & Binary & & 0.450 & 0.498 \\
\hline Movies & Binary & & 0.265 & 0.442 \\
\hline Classical music & Binary & & 0.104 & 0.305 \\
\hline $\begin{array}{l}\text { Mother interested: } \\
\text { sport }\end{array}$ & Binary & & 0.114 & 0.318 \\
\hline Movies & Binary & & 0.229 & 0.420 \\
\hline Classical music & Binary & & 0.114 & 0.318 \\
\hline
\end{tabular}

Source: Author's estimations 


\section{Empirical Results}

It turns out that the intergenerational transfer hypothesis seems to be confirmed after controlling the effects of education, gender, age and hourly wages. The inverse Mills ratio obtained from the exercising any sports probit equation is statistically significant and it has the correct negative sign indicating that the truncated distribution of exercising any sports is a reasonable assumption. The coefficient of the inverse Mills ratio in Table 4 is larger is the sport demand function $\left[\log \left(\mathrm{m} / 1_{\text {sport }}\right)\right]$ than in the movie demand function $\left[\log \left(\mathrm{m} / \mathrm{l}_{\text {movie }}\right)\right]$ which is sensible since the inverse Mills ratio is explaining a dichotomous sport participation.

Table 4. SUR Demand System Estimates, Sport and Movies

\begin{tabular}{|c|c|c|c|c|c|c|}
\hline & Sport & Movies & Sport & Movies & Sport & Movies \\
\hline & $\begin{array}{c}\log \\
\left(\mathrm{m} / \mathrm{l}_{\text {sport }}\right)\end{array}$ & $\begin{array}{c}\log \\
\left(\mathrm{m} / \mathrm{l}_{\text {movie }}\right)\end{array}$ & $\begin{array}{c}\log \\
\left(\mathrm{m} / \mathrm{l}_{\text {sport }}\right)\end{array}$ & $\begin{array}{c}\log \\
\left(\mathrm{m} / \mathrm{l}_{\text {movie }}\right)\end{array}$ & $\begin{array}{c}\log \\
\left(\mathrm{m} / \mathrm{l}_{\text {sport }}\right)\end{array}$ & $\begin{array}{c}\log \\
\left(\mathrm{m} / \mathrm{l}_{\text {movie }}\right)\end{array}$ \\
\hline $\log w$ & $\begin{array}{c}0.402 \\
(0.028)^{* * *}\end{array}$ & $\begin{array}{c}0.340 \\
(0.039)^{* * *}\end{array}$ & $\begin{array}{c}0.395 \\
(0.029)^{* * *}\end{array}$ & $\begin{array}{c}0.344 \\
(0.039)^{* * * *}\end{array}$ & $\begin{array}{c}0.402 \\
(0.029)^{* * *}\end{array}$ & $\begin{array}{c}0.342 \\
(0.039)^{* * *}\end{array}$ \\
\hline $\begin{array}{l}\text { Vocational } \\
\text { education }\end{array}$ & $\begin{array}{c}0.271 \\
(0.095)^{* *}\end{array}$ & $\begin{array}{l}-0.022 \\
(0.129)\end{array}$ & $\begin{array}{c}0.284 \\
(0.097)^{* *}\end{array}$ & $\begin{array}{l}-0.038 \\
(0.130)\end{array}$ & $\begin{array}{c}0.272 \\
(0.095)^{* *}\end{array}$ & $\begin{array}{l}-0.023 \\
(0.128)\end{array}$ \\
\hline $\begin{array}{l}\text { College } \\
\text { degree }\end{array}$ & $\begin{array}{l}-0.132 \\
(0.102)\end{array}$ & $\begin{array}{l}-0.111 \\
(0.138)\end{array}$ & $\begin{array}{l}-0.134 \\
(0.104)\end{array}$ & $\begin{array}{l}-0.107 \\
(0.139)\end{array}$ & $\begin{array}{l}-0.126 \\
(0.102)\end{array}$ & $\begin{array}{l}-0.095 \\
(0.138) \\
\end{array}$ \\
\hline $\begin{array}{l}\text { Bachelor's } \\
\text { degree }\end{array}$ & $\begin{array}{c}-0.238 \\
(0.130)^{(*)}\end{array}$ & $\begin{array}{l}-0.460 \\
(0.177)^{* *}\end{array}$ & $\begin{array}{c}-0.248 \\
(0.133)^{(*)}\end{array}$ & $\begin{array}{l}-0.419 \\
(0.178)^{*}\end{array}$ & $\begin{array}{c}-0.231 \\
(0.131)^{(*)}\end{array}$ & $\begin{array}{l}-0.438 \\
(0.177)^{*}\end{array}$ \\
\hline $\begin{array}{l}\text { Master's } \\
\text { degree }\end{array}$ & $\begin{array}{c}-0.412 \\
(0.110)^{* * *}\end{array}$ & $\begin{array}{l}-0.617 \\
(0.149)^{* * * *}\end{array}$ & $\begin{array}{c}-0.455 \\
(0.112)^{* * *}\end{array}$ & $\begin{array}{c}-0.621 \\
(0.150)^{* * *}\end{array}$ & $\begin{array}{c}-0.408 \\
(0.110)^{* * *}\end{array}$ & $\begin{array}{c}-0.600 \\
(0.149)^{* * *}\end{array}$ \\
\hline $\begin{array}{l}\text { Doctoral } \\
\text { degree }\end{array}$ & $\begin{array}{l}-0.150 \\
(0.227)\end{array}$ & $\begin{array}{c}-1.041 \\
(0.307)^{* * *}\end{array}$ & $\begin{array}{l}-0.191 \\
(0.230)\end{array}$ & $\begin{array}{c}-1.078 \\
(0.309)^{* * * *}\end{array}$ & $\begin{array}{l}-0.154 \\
(0.227)\end{array}$ & $\begin{array}{c}-1.039 \\
(0.306)^{* * *}\end{array}$ \\
\hline Female & $\begin{array}{c}-0.626 \\
(0.065)^{* * * *}\end{array}$ & $\begin{array}{c}-0.416 \\
(0.087)^{* * * *}\end{array}$ & $\begin{array}{c}-0.623 \\
(0.066)^{* * * *}\end{array}$ & $\begin{array}{c}-0.433 \\
(0.088)^{* * * *}\end{array}$ & $\begin{array}{c}-0.631 \\
(0.065)^{* * *}\end{array}$ & $\begin{array}{c}-0.434 \\
(0.088)^{* * *}\end{array}$ \\
\hline Age: 15 - 24 & $\begin{array}{c}-0.937 \\
(0.127)^{* * *}\end{array}$ & $\begin{array}{c}-1.624 \\
(0.172)^{* * *}\end{array}$ & $\begin{array}{c}-0.999 \\
(0.129)^{* * * *}\end{array}$ & $\begin{array}{c}-1.586 \\
(0.173)^{* * *}\end{array}$ & $\begin{array}{c}-0.930 \\
(0.128)^{* * *}\end{array}$ & $\begin{array}{c}-1.600 \\
(0.172)^{* * *}\end{array}$ \\
\hline Age: 25 - 34 & $\begin{array}{c}0.011 \\
(0.111)\end{array}$ & $\begin{array}{c}-0.713 \\
(0.150)^{* * *}\end{array}$ & $\begin{array}{l}-0.009 \\
(0.113)\end{array}$ & $\begin{array}{c}-0.660 \\
(0.151)^{* * *}\end{array}$ & $\begin{array}{c}0.012 \\
(0.111)\end{array}$ & $\begin{array}{c}-0.697 \\
(0.150)^{* * *}\end{array}$ \\
\hline Age: 45 - 54 & $\begin{array}{l}-0.033 \\
(0.105) \\
\end{array}$ & $\begin{array}{c}0.279 \\
(0.142)^{*}\end{array}$ & $\begin{array}{l}-0.039 \\
(0.107) \\
\end{array}$ & $\begin{array}{c}0.316 \\
(0.143)^{*}\end{array}$ & $\begin{array}{l}-0.036 \\
(0.105) \\
\end{array}$ & $\begin{array}{c}0.283 \\
(0.142)^{*} \\
\end{array}$ \\
\hline Age: 55 - 64 & $\begin{array}{l}-0.133 \\
(0.102)\end{array}$ & $\begin{array}{c}0.397 \\
(0.139)^{* *}\end{array}$ & $\begin{array}{l}-0.103 \\
(0.104)\end{array}$ & $\begin{array}{c}0.458 \\
(0.139)^{* * *}\end{array}$ & $\begin{array}{l}-0.142 \\
(0.103)\end{array}$ & $\begin{array}{c}0.388 \\
(0.139)^{* *}\end{array}$ \\
\hline Age: $65+$ & $\begin{array}{c}-1.244 \\
(0.133)^{* * *}\end{array}$ & $\begin{array}{c}-0.342 \\
(0.180)^{(*)}\end{array}$ & $\begin{array}{c}-1.158 \\
(0.135)^{* * * *}\end{array}$ & $\begin{array}{l}-0.284 \\
(0.181)\end{array}$ & $\begin{array}{c}-1.257 \\
(0.134)^{* * *}\end{array}$ & $\begin{array}{c}-0.367 \\
(0.180)^{*}\end{array}$ \\
\hline $\begin{array}{l}\text { Inverse Mills } \\
\text { ratio }\end{array}$ & $\begin{array}{c}-2.537 \\
(0.046)^{* * *} \\
\end{array}$ & $\begin{array}{c}-0.172 \\
(0.062)^{* *} \\
\end{array}$ & $\begin{array}{c}-2.536 \\
(0.047)^{* * *} \\
\end{array}$ & $\begin{array}{c}-0.184 \\
(0.063)^{* *} \\
\end{array}$ & $\begin{array}{l}-2.536 \\
(0.046)\end{array}$ & $\begin{array}{c}-0.173 \\
(0.062)^{* *}\end{array}$ \\
\hline $\begin{array}{l}\text { Father: Sport } \\
\text { interested }\end{array}$ & $\begin{array}{l}-0.238 \\
(0.065)^{* * *}\end{array}$ & & & $\begin{array}{l}-0.184 \\
(0.089)^{*}\end{array}$ & $\begin{array}{c}-0.255 \\
(0.067)^{* * *}\end{array}$ & $\begin{array}{l}-0.187 \\
(0.090)^{*}\end{array}$ \\
\hline $\begin{array}{l}\text { Mother: Sport } \\
\text { interested }\end{array}$ & $\begin{array}{l}-0.472 \\
(0.100)^{* * *}\end{array}$ & & & $\begin{array}{c}0.178 \\
(0.136) \\
\end{array}$ & $\begin{array}{l}-0.450 \\
(0.102)^{* * *}\end{array}$ & $\begin{array}{c}0.135 \\
(0.138) \\
\end{array}$ \\
\hline $\begin{array}{l}\text { Father: Movie } \\
\text { interested }\end{array}$ & & $\begin{array}{l}-0.265 \\
(0.105)^{*}\end{array}$ & $\begin{array}{l}-0.083 \\
(0.079)\end{array}$ & & $\begin{array}{l}-0.076 \\
(0.079) \\
\end{array}$ & $\begin{array}{l}-0.263 \\
(0.107)^{*}\end{array}$ \\
\hline $\begin{array}{l}\text { Mother: Movie } \\
\text { interested }\end{array}$ & & $\begin{array}{l}-0.321 \\
(0.110)^{* *}\end{array}$ & $\begin{array}{l}-0.003 \\
(0.082) \\
\end{array}$ & & $\begin{array}{c}0.016 \\
(0.083) \\
\end{array}$ & $\begin{array}{c}-0.313 \\
(0.112)^{* *}\end{array}$ \\
\hline Constant & $\begin{array}{c}7.278 \\
(0.165)^{* * * *}\end{array}$ & $\begin{array}{c}10.750 \\
(0.224)^{* * *}\end{array}$ & $\begin{array}{c}7.169 \\
(0.168)^{* * * *}\end{array}$ & $\begin{array}{c}10.619 \\
(0.225)^{* * * *}\end{array}$ & $\begin{array}{c}7.307 \\
(0.167)^{* * *}\end{array}$ & $\begin{array}{c}10.811 \\
(0.225)^{* * * *}\end{array}$ \\
\hline $\mathbf{R}^{2}$ & 0.711 & 0.238 & 0.702 & 0.228 & 0.710 & 0.240 \\
\hline $\mathbf{F}$ & $228.04^{* * * *}$ & $29.90^{* * * *}$ & $218.95^{* * * *}$ & $28.24^{* * * *}$ & $201.14^{* * * *}$ & $26.71^{* * * *}$ \\
\hline
\end{tabular}

Source: Author's estimations 
The positive coefficients of hourly wage $(\log w)$ demonstrate that the demand for sports and movies at a cinema decrease with hourly wages indicating that the opportunity cost of time spent on these activities is a valid argument. It must be recalled that a positive sign of a coefficient shows a negative effect on sport or movie demand since these activities are the denominators of the variables to be explained. The monthly household salaries (the numerator of the dependent variable) and personal hourly wage are correlated therefore the separation of the opportunity cost effect and the effect of positive correlation of household and personal incomes is not simple. Hence the opportunity cost argument must be assessed with caution. Vocational education has a positive sign in the sport demand equation while either a bachelor's or master's degree have a negative sign showing that education is related to healthy behaviour. Higher educated are more sporty people. They seem to attend also more movies at a cinema. The highest education, a doctor's degree is also related positively to movies but not the sport. Gender is important. Women are more active sport exercisers and also more active visitors at a cinema. Employed women on average have less working hours than employed men, however women have more housework. The youngest (15-24) and the oldest (more than 65) age groups are more active sport exercisers. The age groups from 25 to 34 and from 45 to 64 are not significantly different to the reference group: 35 to 44 years old. In the case of movies at a cinema, the age groups 45 to 54 and 55 to 64 seem to have the lowest attendance figure. Younger and older are more active in movie attendance.

The intergenerational transfer hypothesis is valid. If a person's father or mother was active then also the person is active both in sport and movie participation. In general the cross effect are not significant, a sporty father or a sporty mother does not increase movie participation and an active parent movie attender does not increase the possibility of sport participation of the child. However, an active father who was exercising sport seem to have a positive relation to movie attendance. The same is not verified in the case of a sporty active mother.

For robustness reasons the above system equations have been done with a combination of sport and classical music. The results are shown in Table 5 . The inverse Mills ratio is not significant in the case of classical music, hence the unobservable variables of sport participation that explain hours used in sport activities do not explain hours used in classical music attendance. The intergenerational transfer hypothesis is valid also in the case of classical music. If a person's parent were interested in classical music the person is also active in classical music and used more hours to participate classical music concerts. The opportunity cost of time spent on classical music concerts is important and statistically significant. The effects of education and age are as expected. Higher educated use more time in classical music concerts. The middle aged persons or somewhat younger (25-44 years old) seem to use less time in classical music concerts. 
The cross intergenerational effects from mother's sporty behaviour does not have any effect on time spent on classical music, however, the effect from father's sporty behaviour are positive. This father's influence is also valid in the case of movie attendance. Father's sporty behaviour and classical music engagement are not correlated on average, however it seems that if a person's father is sporty and goes to classical music concerts the children also favours classical music concerts. The result is unexpected and surprising.

Table 5. SUR Demand System Estimates, Sport and Classical Music

\begin{tabular}{|c|c|c|c|c|c|c|}
\hline & Sport & $\begin{array}{l}\text { Classical } \\
\text { music }\end{array}$ & Sport & $\begin{array}{l}\text { Classical } \\
\text { music }\end{array}$ & Sport & $\begin{array}{l}\text { Classical } \\
\text { music }\end{array}$ \\
\hline & $\log \left(m / l_{\text {sport }}\right)$ & $\log \left(m / l_{c l_{\_} m u}\right)$ & $\log \left(m / l_{\text {sport }}\right)$ & $\log \left(m / l_{c l_{\_} m u}\right)$ & $\log \left(m / l_{\text {sport }}\right)$ & $\log \left(m / l_{c l_{\_} m u}\right)$ \\
\hline $\log w$ & $\begin{array}{c}0.402 \\
(0.029)^{\text {***** }}\end{array}$ & $\begin{array}{c}0.364 \\
(0.037)^{* * * *}\end{array}$ & $\begin{array}{c}0.396 \\
(0.029)^{* * *}\end{array}$ & $\begin{array}{c}0.365 \\
(0.038)^{* * * *}\end{array}$ & $\begin{array}{c}0.403 \\
(0.029)^{* * * *}\end{array}$ & $\begin{array}{c}0.366 \\
(0.037)^{\text {***** }}\end{array}$ \\
\hline $\begin{array}{l}\text { Vocational } \\
\text { education }\end{array}$ & $\begin{array}{c}0.271 \\
(0.095)^{\text {** }}\end{array}$ & $\begin{array}{c}0.039 \\
(0.123)\end{array}$ & $\begin{array}{c}0.281 \\
(0.097)^{* *}\end{array}$ & $\begin{array}{c}0.061 \\
(0.127)\end{array}$ & $\begin{array}{c}0.269 \\
(0.095)^{* *}\end{array}$ & $\begin{array}{c}0.035 \\
(0.123)\end{array}$ \\
\hline $\begin{array}{l}\text { College } \\
\text { degree }\end{array}$ & $\begin{array}{l}-0.130 \\
(0.102) \\
\end{array}$ & $\begin{array}{l}-0.142 \\
(0.132) \\
\end{array}$ & $\begin{array}{l}-0.137 \\
(0.104) \\
\end{array}$ & $\begin{array}{l}-0.142 \\
(0.136) \\
\end{array}$ & $\begin{array}{l}-0.128 \\
(0.102) \\
\end{array}$ & $\begin{array}{l}-0.134 \\
(0.132) \\
\end{array}$ \\
\hline $\begin{array}{l}\text { Bachelor's } \\
\text { degree }\end{array}$ & $\begin{array}{c}-0.237 \\
(0.130)^{(*)}\end{array}$ & $\begin{array}{l}-0.335 \\
(0.169)^{*}\end{array}$ & $\begin{array}{c}-0.248 \\
(0.133)^{(*)}\end{array}$ & $\begin{array}{l}-0.441 \\
(0.174)^{*}\end{array}$ & $\begin{array}{c}-0.222 \\
(0.131)^{(*)}\end{array}$ & $\begin{array}{c}-0.322 \\
(0.169)^{(*)}\end{array}$ \\
\hline $\begin{array}{l}\text { Master's } \\
\text { degree }\end{array}$ & $\begin{array}{c}-0.411 \\
(0.110)^{\text {**** }}\end{array}$ & $\begin{array}{c}-0.952 \\
(0.143)^{\text {**** }}\end{array}$ & $\begin{array}{c}-0.450 \\
(0.112)^{* * * *}\end{array}$ & $\begin{array}{c}-1.104 \\
(0.147)^{* * *}\end{array}$ & $\begin{array}{c}-0.389 \\
(0.111)^{* * * *}\end{array}$ & $\begin{array}{c}-0.930 \\
(0.143)^{* * * *}\end{array}$ \\
\hline $\begin{array}{l}\text { Doctoral } \\
\text { degree }\end{array}$ & $\begin{array}{l}-0.151 \\
(0.227)\end{array}$ & $\begin{array}{c}-1.284 \\
(0.293)^{* * *}\end{array}$ & $\begin{array}{l}-0.182 \\
(0.230)\end{array}$ & $\begin{array}{c}-1.444 \\
(0.302)^{* * *}\end{array}$ & $\begin{array}{l}-0.130 \\
(0.227)\end{array}$ & $\begin{array}{c}-1.268 \\
(0.293)^{* * * *}\end{array}$ \\
\hline Female & $\begin{array}{c}-0.628 \\
(0.065)^{\text {**** }} \\
\end{array}$ & $\begin{array}{c}-0.533 \\
(0.083)^{* * * *} \\
\end{array}$ & $\begin{array}{c}-0.620 \\
(0.066)^{* * *} \\
\end{array}$ & $\begin{array}{c}-0.553 \\
(0.086)^{* * *} \\
\end{array}$ & $\begin{array}{c}-0.627 \\
(0.065)^{* * *} \\
\end{array}$ & $\begin{array}{c}-0.541 \\
(0.084)^{* * *}\end{array}$ \\
\hline Age: 15 - 24 & $\begin{array}{c}-0.936 \\
(0.127)^{* * *}\end{array}$ & $\begin{array}{c}-0.666 \\
(0.164)^{* * *}\end{array}$ & $\begin{array}{l}-1.000 \\
(0.129)^{* * *}\end{array}$ & $\begin{array}{l}-0.665 \\
(0.170)^{* * * *}\end{array}$ & $\begin{array}{l}-0.930 \\
(0.127)^{* * * *}\end{array}$ & $\begin{array}{l}-0.636 \\
(0.165)^{* * * *}\end{array}$ \\
\hline Age: 25 - 34 & $\begin{array}{c}0.012 \\
(0.111)\end{array}$ & $\begin{array}{c}0.137 \\
(0.143) \\
\end{array}$ & $\begin{array}{l}-0.007 \\
(0.112)\end{array}$ & $\begin{array}{c}0.160 \\
(0.148)\end{array}$ & $\begin{array}{c}0.011 \\
(0.111)\end{array}$ & $\begin{array}{c}0.148 \\
(0.143)\end{array}$ \\
\hline Age: 45 - 54 & $\begin{array}{l}-0.033 \\
(0.105) \\
\end{array}$ & $\begin{array}{c}-0.275 \\
(0.136)^{*}\end{array}$ & $\begin{array}{c}-0.034 \\
(0.107) \\
\end{array}$ & $\begin{array}{c}-0.267 \\
(0.140)^{(*)} \\
\end{array}$ & $\begin{array}{l}-0.033 \\
(0.105) \\
\end{array}$ & $\begin{array}{c}-0.273 \\
(0.136)^{*}\end{array}$ \\
\hline Age: 55 - 64 & $\begin{array}{l}-0.133 \\
(0.102)\end{array}$ & $\begin{array}{c}-0.701 \\
(0.132)^{* * *}\end{array}$ & $\begin{array}{l}-0.093 \\
(0.104)\end{array}$ & $\begin{array}{c}-0.685 \\
(0.136)^{* * * *}\end{array}$ & $\begin{array}{l}-0.138 \\
(0.102)\end{array}$ & $\begin{array}{c}-0.718 \\
(0.132)^{* * *}\end{array}$ \\
\hline Age: $65+$ & $\begin{array}{c}-1.244 \\
(0.133)^{\text {**** }}\end{array}$ & $\begin{array}{c}-1.855 \\
(0.171)^{* * *}\end{array}$ & \begin{tabular}{|c|}
-1.145 \\
$(0.134)^{* * *}$
\end{tabular} & $\begin{array}{c}-1.872 \\
(0.177)^{* * *}\end{array}$ & $\begin{array}{c}-1.248 \\
(0.133)^{* * *}\end{array}$ & $\begin{array}{l}-1.895 \\
(0.172)^{* * * *}\end{array}$ \\
\hline $\begin{array}{l}\text { Inverse Mills } \\
\text { ratio }\end{array}$ & $\begin{array}{c}-2.537 \\
(0.046)^{* * *}\end{array}$ & $\begin{array}{l}-0.076 \\
(0.060)\end{array}$ & $\begin{array}{c}-2.537 \\
(0.047)^{* * *} \\
\end{array}$ & $\begin{array}{c}-0.084 \\
(0.061)\end{array}$ & $\begin{array}{c}-2.536 \\
(0.046)^{* * *}\end{array}$ & $\begin{array}{l}-0.076 \\
(0.060)\end{array}$ \\
\hline $\begin{array}{l}\text { Father: Sport } \\
\text { interested }\end{array}$ & $\begin{array}{l}-0.250 \\
(0.066)^{* * * *}\end{array}$ & & & $\begin{array}{l}-0.115 \\
(0.087)\end{array}$ & $\begin{array}{c}-0.261 \\
(0.066)^{* * *}\end{array}$ & $\begin{array}{c}-0.140 \\
(0.085)^{(*)}\end{array}$ \\
\hline $\begin{array}{l}\text { Mother: Sport } \\
\text { interested }\end{array}$ & $\begin{array}{l}-0.444 \\
(0.101)^{* * *}\end{array}$ & & & $\begin{array}{l}-0.047 \\
(0.134) \\
\end{array}$ & $\begin{array}{l}-0.451 \\
(0.101)^{* * *}\end{array}$ & $\begin{array}{l}-0.098 \\
(0.131) \\
\end{array}$ \\
\hline $\begin{array}{l}\text { Father: CMus } \\
\text { interested }\end{array}$ & & $\begin{array}{l}-0.561 \\
(0.143)^{* * *} \\
\end{array}$ & $\begin{array}{c}0.001 \\
(0.112) \\
\end{array}$ & & $\begin{array}{l}-0.049 \\
(0.111) \\
\end{array}$ & $\begin{array}{l}-0.569 \\
(0.143)^{* * *}\end{array}$ \\
\hline $\begin{array}{l}\text { Mother: CMus } \\
\text { interested }\end{array}$ & & $\begin{array}{c}-0.908 \\
(0.137)^{* * *}\end{array}$ & $\begin{array}{l}-0.057 \\
(0.108)\end{array}$ & & $\begin{array}{l}-0.123 \\
(0.107)\end{array}$ & $\begin{array}{c}-0.919 \\
(0.138)^{* * *}\end{array}$ \\
\hline Constant & $\begin{array}{c}7.280 \\
(0.165)^{\text {*** }} \\
\end{array}$ & $\begin{array}{c}13.199 \\
(0.211)^{* * * *} \\
\end{array}$ & $\begin{array}{c}7.141 \\
(0.166) \\
\end{array}$ & $\begin{array}{c}13.127 \\
(0.220)^{* * *} \\
\end{array}$ & $\begin{array}{c}7.300 \\
(0.165)^{* * *} \\
\end{array}$ & $\begin{array}{c}13.267 \\
(0.213)^{* * *} \\
\end{array}$ \\
\hline $\mathbf{R}^{2}$ & 0.711 & 0.202 & 0.702 & 0.153 & 0.711 & 0.203 \\
\hline $\mathbf{F}$ & $228.06^{* \cdots * k}$ & $24.44^{* * * *}$ & $218.61^{* * * * *}$ & $17.65^{* * * *}$ & $201.38^{* * * *}$ & $21.82^{* * * *}$ \\
\hline
\end{tabular}

Source: Author's estimations 
Finally the intergenerational transfer hypothesis is studied using three age categories: young (15-34 years), middle-aged (35-54 years) and old (more than 55 years) and time used for sport exercising and for movies. The results are shown Table 6. Some interesting results are seen. The sport activity is transferred from father to child in each age category while the oldest sport exercisers do not inherit the sport activity from their mother. The inheritance from mother is valid when the person is younger than 55 . The reverse seems to be valid in the case of movies: the inheritance from mother is more probable than from father. An interesting impact of education can be seen in the Table 6 . If a person older than 55 has a vocational education, the possibility of exercising sport is lower than with other educational levels. The other education levels (college, bachelor, master, doctor) are significantly more inclined to sport exercising if the person's age is between 35 and 54 . Bachelor and master degree are significant if the sport exerciser is less than 35 (or 55) years old. A high education has also a strong positive influence on the movies at a cinema attendance if the person is older than 35 but the conclusion does not seem to hold if the person is younger than 35 .

Table 6. SUR Demand System Estimates, Sport and Movies, Age Categories

\begin{tabular}{|c|c|c|c|c|c|c|}
\hline & \multicolumn{2}{|c|}{ Only $15-34$ years old } & \multicolumn{2}{|c|}{ Only 35-54 years old } & \multicolumn{2}{|c|}{ Only 55- years old } \\
\hline & Sport & Movies & Sport & Movies & Sport & Movies \\
\hline & $\log \left(m / l_{\text {sport }}\right)$ & $\log \left(\mathrm{m} / \mathrm{l}_{\text {movie }}\right)$ & $\log \left(m / l_{\text {sport }}\right)$ & $\log \left(\mathrm{m} / \mathrm{l}_{\text {movie }}\right)$ & $\log \left(m / l_{\text {sport }}\right)$ & $\log \left(\mathrm{m} / \mathrm{l}_{\text {movie }}\right)$ \\
\hline Log w & $0.481^{\text {**** }}$ & $0.402^{* * *}$ & $0.456^{\text {***** }}$ & $0.363^{\text {**** }}$ & $0.331^{\text {**** }}$ & $0.307^{* * *}$ \\
\hline $\begin{array}{l}\text { Vocational } \\
\text { education }\end{array}$ & $0.339^{*}$ & $0.710^{* * *}$ & 0.045 & -0.372 & $0.386^{*}$ & $-0.317^{(*)}$ \\
\hline $\begin{array}{l}\text { College } \\
\text { degree }\end{array}$ & -0.098 & $1.114^{* \text { **** }}$ & $-0.414^{* *}$ & $-0.769^{* *}$ & 0.035 & -0.088 \\
\hline $\begin{array}{l}\text { Bachelor's } \\
\text { degree }\end{array}$ & $-0.451^{*}$ & 0.089 & $-0.432^{*}$ & $-0.768^{*}$ & 0.284 & $-0.918^{*}$ \\
\hline $\begin{array}{l}\text { Master's } \\
\text { degree }\end{array}$ & $-0.822^{* *}$ & -0.224 & $-0.418^{*}$ & $-0.784^{* *}$ & -0.283 & $-1.020^{* F^{*}}$ \\
\hline $\begin{array}{l}\text { Doctoral } \\
\text { degree }\end{array}$ & -0.352 & -0.543 & $-0.557^{(*)}$ & $-1.821^{* * *}$ & 0.273 & -0.715 \\
\hline Female & $-0.572^{* * * *}$ & -0.283 & $-0.463^{\text {*k* }}$ & $-0.414^{* *}$ & $-0.802^{* \cdots *}$ & $-0.545^{* \ldots *}$ \\
\hline Age: 15 - 24 & $-1.064^{* * *}$ & $-0.699^{* * *}$ & (not applicable) & (not applicable) & (not applicable) & (not applicable) \\
\hline Age: 25 - 34 & (not applicable) & (not applicable) & (not applicable) & (not applicable) & (not applicable) & (not applicable) \\
\hline Age: 35 - 44 & (not applicable) & (not applicable) & 0.024 & $-0.272^{*}$ & (not applicable) & (not applicable) \\
\hline Age: $45-54$ & (not applicable) & (not applicable) & (not applicable) & (not applicable) & (not applicable) & (not applicable) \\
\hline Age: 55 - 64 & (not applicable) & (not applicable) & (not applicable) & (not applicable) & 0.972 & $0.733^{\text {**** }}$ \\
\hline Age: 65 - & (not applicable) & (not applicable) & (not applicable) & (not applicable) & (not applicable) & (not applicable) \\
\hline $\begin{array}{l}\text { Inverse Mills } \\
\text { ratio }\end{array}$ & $-2.484^{* * * *}$ & -0.117 & $-2.581^{\text {**** }}$ & -0.144 & $-2.510^{* * * *}$ & $-0.175^{(*)}$ \\
\hline $\begin{array}{l}\text { Father: Sport } \\
\text { interested }\end{array}$ & $-0.229^{(*)}$ & 0.077 & $-0.223^{* *}$ & -0.188 & $-0.321^{*}$ & $-0.353^{*}$ \\
\hline $\begin{array}{l}\text { Mother: Sport } \\
\text { interested }\end{array}$ & $-0.504^{* *}$ & -0.162 & $-0.472^{* * *}$ & $0.353^{(*)}$ & -0.288 & 0.123 \\
\hline $\begin{array}{l}\text { Father: Movie } \\
\text { interested }\end{array}$ & -0.039 & -0.295 & -0.108 & $-0.340^{*}$ & -0.054 & -0.095 \\
\hline $\begin{array}{l}\text { Mother: Movie } \\
\text { interested }\end{array}$ & 0.185 & $-0.393^{(*)}$ & -0.023 & $-0.253^{(*)}$ & -0.055 & $-0.357^{(*)}$ \\
\hline Constant & $7.071^{* * *}$ & $9.129^{* * * *}$ & $7.153^{* * * *}$ & $11.366^{* * * *}$ & $6.488^{* * * *}$ & $10.879^{* * * *}$ \\
\hline $\mathbf{R}^{2}$ & 0.729 & 0.140 & 0.758 & 0.112 & 0.666 & 0.115 \\
\hline $\mathbf{F}$ & $80.01^{* * * \pi}$ & $85.37^{* * 21}$ & $120.31^{\text {*** }}$ & $86.29^{* \cdots * k}$ & $78.93^{* * * *}$ & $6.06^{* * * *}$ \\
\hline
\end{tabular}

Source: Author's estimations 
For robustness reasons the same age categories are used to estimate the intergenerational transfer effects in the case of sport and classical music concerts. The results is shown in Table 7. The influence of mother is more important than the influence of father in classical music concert attendance. The transfer is similar than in the case of movies at a cinema. The overall results indicate that father's influence is more important in exercising sport and the mother's influence is more important in attending both movies at a cinema or classical music concerts especially when the person is more than 55 years old. When the person is younger than 55 the influence of both father and mother seem to work. It underlines the role model assumption, parents' stimulation is credible as Downward et al. (2014) argue. They discover that particularly for male adults and male children the intergenerational transfer effects are strong. Hirvensalo (2002) points out that the permanence of physical activity. If a young person was a physically active then person is probably active also more aged.

Table 7. SUR Demand System Estimates, Sport and Classical Music, Age Categories

\begin{tabular}{|c|c|c|c|c|c|c|}
\hline & \multicolumn{2}{|c|}{ Only 15-34 years old } & \multicolumn{2}{|c|}{ Only 35-54 years old } & \multicolumn{2}{|c|}{ Only 55- years old } \\
\hline & Sport & $\begin{array}{l}\text { Classical } \\
\text { music }\end{array}$ & Sport & $\begin{array}{l}\text { Classical } \\
\text { music }\end{array}$ & Sport & $\begin{array}{l}\text { Classical } \\
\text { music }\end{array}$ \\
\hline & $\log \left(m / l_{\text {sport }}\right)$ & $\log \left(m / l_{c l m u}\right.$ & $\log \left(m / l_{\text {sport }}\right)$ & $\log \left(m / l_{c l m u}\right.$ & $\log \left(m / l_{\text {sport }}\right)$ & $\log \left(m / l_{c l m u}\right)$ \\
\hline $\log w$ & $0.477^{* * * 3}$ & $0.524^{* * * *}$ & 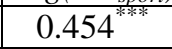 & $0.330^{* * *}$ & $0.334^{* * * 3}$ & $0.287^{\text {**ak }}$ \\
\hline $\begin{array}{l}\text { Vocational } \\
\text { education }\end{array}$ & $0.297^{(*)}$ & $0.634^{* *}$ & 0.038 & -0.277 & $0.385^{*}$ & -0.164 \\
\hline College degree & -0.133 & $0.475^{(*)}$ & $-0.422^{* * *}$ & $-0.518^{*}$ & 0.042 & -0.285 \\
\hline Bachelor's degree & $-0.473^{* * *}$ & 0.306 & $-0.433^{*}$ & $-0.863^{* * *}$ & 0.316 & $-0.882^{*}$ \\
\hline Master's degree & $-0.814^{* * * *}$ & -0.346 & $-0.411^{*}$ & $-1.255^{* * *}$ & -0.236 & $-1.260^{* * * *}$ \\
\hline Doctoral degree & -0.328 & 0.363 & $-0.545^{(*)}$ & $-1.579^{* * *}$ & 0.359 & $-1.586^{* * *}$ \\
\hline Female & $-0.565^{* * *}$ & $-0.396^{* * *}$ & $-0.449^{* * * *}$ & $-0.268^{(*)}$ & $-0.804^{* * * *}$ & $-0.930^{* * *}$ \\
\hline Age: 15 - 24 & $-1.062^{* * * *}$ & $-0.624^{* * * *}$ & (not applicable) & (not applicable) & (not applicable) & (not applicable) \\
\hline Age: 25 - 34 & (not applicable) & (not applicable) & (not applicable) & (not applicable) & (not applicable) & (not applicable) \\
\hline Age: 35 - 44 & (not applicable) & (not applicable) & 0.016 & $0.267^{*}$ & (not applicable) & (not applicable) \\
\hline Age: 45 - 54 & (not applicable) & (not applicable) & (not applicable) & (not applicable) & (not applicable) & (not applicable) \\
\hline Age: 55 - 64 & (not applicable) & (not applicable) & (not applicable) & (not applicable) & $0.973^{* * *}$ & $1.040^{* * * *}$ \\
\hline Age: 65 - & (not applicable) & (not applicable) & (not applicable) & (not applicable) & (not applicable) & (not applicable) \\
\hline $\begin{array}{l}\text { Inverse Mills } \\
\text { ratio }\end{array}$ & $-2.500^{* * * *}$ & -0.065 & $-2.584^{* * *}$ & -0.043 & $-2.507^{* * *}$ & -0.056 \\
\hline $\begin{array}{l}\text { Father: Sport } \\
\text { interested }\end{array}$ & $-0.235^{(*)}$ & 0.017 & $-0.243^{\text {** }}$ & $-0.269^{*}$ & $-0.324^{*}$ & -0.123 \\
\hline $\begin{array}{l}\text { Mother: Sport } \\
\text { interested }\end{array}$ & $-0.479^{* * *}$ & $-0.415^{*}$ & $-0.487^{* * * *}$ & 0.054 & -0.287 & 0.038 \\
\hline $\begin{array}{l}\text { Father: CIMu } \\
\text { interested }\end{array}$ & -0.048 & $-0.462^{(*)}$ & -0.066 & $-0.604^{* *}$ & -0.207 & -0.382 \\
\hline $\begin{array}{l}\text { Mother: ClMu } \\
\text { interested }\end{array}$ & $-0.354^{*}$ & $-1.062^{* * * *}$ & 0.051 & $-0.479^{*}$ & -0.081 & $-1.340^{* * * *}$ \\
\hline Constant & $7.179^{\text {**** }}$ & $12.113^{\text {**** }}$ & $7.132^{* * * *}$ & $13.307^{* * *}$ & $6.469^{* * * *}$ & $12.240^{\text {**** }}$ \\
\hline $\mathbf{R}^{2}$ & 0.731 & 0.258 & 0.757 & 0.118 & 0.667 & 0.244 \\
\hline $\mathbf{F}$ & $81.05^{* * * * *}$ & $11.24^{\text {**** }}$ & $119.92^{* *}$ & $89.70^{* * * *}$ & $78.15^{\text {****k }}$ & $13.63^{\text {**** }}$ \\
\hline
\end{tabular}

Source: Author's estimations 
Table 7 demonstrates that the effect of education is important in classical music concert participation. If the person is younger than 35, vocational or college educated seem to participate less and if the person is older than 35 any university degree seems to increase the possibility of going to a classical music concert.

\section{Conclusions}

In this study we estimate demand functions for sport and cultural activities based on data collected in 2007 in Finland. We use a SUR model and CES utility function that take into account the assumption that the demand for sports and other leisure activities are simultaneously determined. This data is collected in autumn 2007 as a part of the larger survey focusing on cultural attitudes of the citizens in Finland. A random sample was chosen and a letter inquiry was sent to 3,000 individuals. The response rate was $46.3 \%$. In addition to the demand for sports, we have information about the demand for movies at a cinema and the demand for classical music concerts but not any price information. Various socio-economic characteristics of the respondents are available including their parent's attitudes or involvement into sport, movies or classical music.

The analysis shows that the attitudes of parents and behaviour affect the physical activity of a child. This result can be partially generalised since father's sporty behaviour seem to inherit to the child even when the person is older than 55. Generally speaking women are more active exercisers in Finland regardless of her age. Women are also more active in terms of movies at a cinema or classical music concert attendance. The intergenerational transfer effects from mother to child are more important in the cases of cinema or classical music concerts. However, father's influence is more important for sporty behaviour.

The demand for sports, movies at a cinema or classical music concerts decrease with hourly wages indicating that the opportunity cost of time spent on these activities is taken into account. While higher incomes allow more active participation in any leisure time activity, the lost income has a negative effect. Retired persons do not suffer from the lost income circumstances and therefore they are more active in sports, movies or classical music concerts than persons who are younger and still working. Highly educated persons seem to be more active sport exercisers indicating that they are aware of the health effects of sport.

Since Finland is a high sport participation country and since the intergenerational transfer effects seem to hold true, it is important that all countries should pursue a health policy favouring sporty behaviour of all adults. Their children follow this behaviour and they are sporty people throughout their life. 


\section{References}

Burenstam Linder S (1970) The Harried Leisure Class. New York: Columbia University Press.

Cabane C, Lechner M (2014) Physical Activity of Adults: A Survey of Correlates, Determinants, and Effects. ZEW Discussion Papers No. 14-088.

Downward P (2007) Exploring the economic choice to participate in sport: results from the 2002 general household survey. International Review of Applied Economics 21: 633653.

Downward P, Hallmann K, Pawlowski T (2014) Assessing parental impact on the sports participation of children: A socio-economic analysis of the UK. European Journal of Sport Science 14: 84-90.

Downward P, Rasciute S (2009) The relative demands for sports and leisure in England. European Sport Management Quarterly 10: 189-214.

Downward P, Rasciute S (2011) Does sport make you happy? An analysis of the well-being derived from sports participation. International Review of Applied Economics 25: 331 348.

Downward P, Rasciute S (2015) Exploring the covariates of sport participation for health: An analysis of males and females in England. Journal of Sports Sciences 33(1): 67-76.

García J, Lera-López F, Suárez MJ (2011) Estimation of a structural model of the determinants of the time spent on physical activity and sport: Evidence for Spain. Journal of Sport Economics 12: 515-537.

Green M, Collins S (2008) Policy, politics and path dependency: Sport development in Australia and Finland. Sport Management Review 11: 225-251.

Hakamäki M, Jaako J, Kankaanpää A, Kantomaa M, Kämppi K, Rajala K, Tammelin T (2014) Sosioekonomisen taustan yhteys lasten ja nuorten liikuntaan. In Mikä maksaa? [Connection of the socio-economic background to the physical education of the children and adolescents. In What costs?] Valtion Liikuntaneuvoston Julkaisuja 2.

Handel G (2006) Childhood Socialization, ( $2^{\text {nd }}$ edn). New Brunswick: Aldine Transaction.

Hirvensalo M (2002) Physical Activity in Old Age - Significance for Public Health and Promotion Strategies. Jyväskylä University.

Lechner M (2009) Long-run labour market and health effects of individual sport activities. The Journal of Health Economics 28: 839-854.

Lera-López F, Rapún-Gárate M (2007) The Demand for Sport: Sport Consumption and Participation Models. Journal of Sport Management 21: 103-122.

Løyland K, Ringstad V (2009) On the price and income sensitivity of the demand for sports: Has Linder's disease become more serious? Journal of Sports Economics 10: 601-618.

Martinez-Gonzalez MA, Varo JJ, Santos JL, de Irala J, Gibney M, Kearney J, Martinez JA (2001) Prevalence of physical activity during leisure time in the European Union. Medicine \& Science in Sports \& Exercise 33: 1142-1146.

Saaristo K, Jokinen K (2009) Sosiologia [Sociology]. Helsinki: WSOYpro.

Scheerder J, Vanreusel B, Taks M (2005) Stratification patterns of active sport involvement among adults. International Review for the Sociology of Sport 40: 139-162.

Seefeldt V, Malina RM, Clark MA (2002) Factors Affecting Levels of Physical Activity in Adults. Sports Medicine 32: 143-168.

Vuori I, Paronen O, Oja P (1998) How to develop local physical activity promotion programmes with national support: the Finnish experience. Patient Education and Couseling 33: S111-S120. 


\section{$\underline{\text { Appendix }}$}

Table 8. Net Personal or Household Incomes, Determination Equations, OLS

\begin{tabular}{|c|c|c|}
\hline & Net personal incomes $(\mathrm{N}=1336)$ & Net household incomes $(\mathrm{N}=\mathbf{1 0 2 6})$ \\
\hline Vocational education & $154.60(91.18)^{(*)}$ & $-128.57(160.50)$ \\
\hline College degree & $494.62(98.33)^{* * * *}$ & $430.59(173.77)^{*}$ \\
\hline Bachelor's degree & $540.18(125.45)^{* * * *}$ & $452.93(220.39)^{*}$ \\
\hline Master's degree & $906.78(105.51)^{* * * *}$ & $946.50(186.15)^{* * * *}$ \\
\hline Doctoral degree & $1468.20(218.29)^{* * * *}$ & $1225.40(382.55)^{* * *}$ \\
\hline Female & $-523.21(62.15)^{* * * *}$ & $-307.34(109.59)^{* *}$ \\
\hline Age: $15-24$ & $-893.37(122.08)^{* * * *}$ & $390.91(224.95)^{(*)}$ \\
\hline Age: 25 - 34 & $-275.48(106.35)^{* * *}$ & $-392.25(186.96)^{*}$ \\
\hline Age: $45-54$ & $84.66(101.36)$ & $-25.16(177.47)$ \\
\hline Age: $55-64$ & $-151.45(98.27)$ & $-433.85(176.46)^{*}$ \\
\hline Age: $65+$ & $-531.78(111.05)^{* * * *}$ & $-830.86(213.20)^{3 * * *}$ \\
\hline Common law marriage & & $2670.97(148.19)^{* * *}$ \\
\hline Marriage & & $2880.68(130.13)^{* * *}$ \\
\hline Hours worked/week & & $12.93(3.05)^{* * * *}$ \\
\hline Constant & $1645.02(109.36)^{* * * *}$ & $-23.35(112.36)$ \\
\hline $\mathrm{R}^{2}$ & 0.186 & 0.353 \\
\hline $\mathrm{F}$ & $29.90^{* * * * *}$ & $55.02^{* * * *}$ \\
\hline
\end{tabular}

Source: Author's estimations

Table 9. A Probit Equation for Being Employed and Working Hours Per Week (OLS) Determination Equation

\begin{tabular}{|c|c|c|}
\hline & Employed (probit) & Working hours per week (OLS) \\
\hline Constant & $0.173(0.143)$ & $22.598(0.845)^{* * * *}$ \\
\hline $\begin{array}{l}\text { Owner-occupied flat with } \\
\text { housing loan }\end{array}$ & $0.244(0.086)^{* * *}$ & $4.238(0.511)^{* * * *}$ \\
\hline Vocational education & $0.335(0.113)^{* *}$ & $4.330(0.670)^{* * *}$ \\
\hline College degree & $0.514(0.125)^{3 * *}$ & $5.564(0.724)^{* * * *}$ \\
\hline Bachelor's degree & $0.406(0.154)^{* *}$ & $4.288(0.923)^{* * * *}$ \\
\hline Master's degree & $0.542(0.133)^{* * *}$ & $4.784(0.776)^{* * * *}$ \\
\hline Doctoral degree & $0.359(0.284)$ & $5.741(1.605)^{* * * *}$ \\
\hline Female & $-0.194(0.079)^{*}$ & $-3.784(0.457)^{* * * *}$ \\
\hline Age: $15-24$ & $-0.759(0.147)^{* * * *}$ & $-15.365(0.915)^{* * *}$ \\
\hline Age: $25-34$ & $-0.198(0.131)$ & $-3.076(0.784)^{* * * *}$ \\
\hline Age: $45-54$ & $0.236(0.134)^{(*)}$ & $2.850(0.753)^{* * * 4}$ \\
\hline Age: $55-64$ & $-0.668(0.123)^{* * * *}$ & $-11.113(0.754)^{* * * *}$ \\
\hline Age: $65+$ & $-2.156(0.178)^{\text {**** }}$ & $-26.113(0.864)^{* * *}$ \\
\hline \multirow[t]{3}{*}{$\begin{array}{l}\text { Inverse Mills ratio (obtained } \\
\text { from probit) }\end{array}$} & & $21.386(0.313)^{* * * *}$ \\
\hline & $\begin{array}{c}\text { McFadden Pseudo } \mathrm{R}^{2} \text { : } \\
0.233\end{array}$ & $\mathrm{R}^{2}: 0.838$ \\
\hline & $\chi^{2}$-test: $442.16^{* * * x}$ & F-test: $554.70^{* * *}$ \\
\hline
\end{tabular}

Source: Author's estimations 